https://doi.org/10.28925/2664-2069.2019.2.9

\title{
СТРАТЕГІЇ ПОДОЛАННЯ СТРЕСУ У КВАЛІФІКОВАНИХ СПОРТСМЕНІВ-ВЕСЛУВАЛЬНИКІВ
}

\author{
Федорчук Світлана ${ }^{1 A B C D}$, Лисенко Олена ${ }^{1,2 A B C D}$ \\ ${ }^{1}$ Національний університет фізичного виховання і спорту Украйни, Київ, Украйна \\ ${ }^{2}$ Київський університет імені Бориса Грінченка, Київ, Україна \\ Внесок автора: А - дизайн дослідження; В - збір даних; \\ $\mathrm{C}$ - статистичний аналіз; D - підготовка рукопису.
}

\begin{abstract}
Анотація
Стресостійкість є одним з основних критеріїв фізичного і психічного здоров'я спортсмена. Уміння особи подолати стрес знижує вплив стресу на частоту травм. У зв'язку з цим важливою стороною психологічної підготовки спортсмена є розвиток його здібностей до подолання стресу, формування вміння ефективного використання стратегій подолання стресу (копінг-стратегій).

Мета - визначити, які саме типи копінг-стратегій характерні для кваліфікованих спортсменіввеслувальників.

Методи. Для визначення пріоритетного стилю подолання стресових ситуацій або проблем у спортсменів був використаний опитувальник «Виявлення індивідуальних копінг-стратегій» Е. Хайма.

Результати. Найбільш поширеними копінг-стратегіями серед обстежених спортсменів були: в когнітивної сфері - «проблемний аналіз»; в емоційній сфері - «оптимізм»; в поведінкової сфері «відволікання». У цілому, серед кваліфікованих спортсменів-веслувальників кількісно переважало використання «адаптивних» стратегій у порівнянні з «неадаптивними» і «відносно адаптивними».

Висновки. Встановлено, що серед адаптивних копінг-стратегій найбільш поширеними у спортсменів є емоційні адаптивні стратегії, а серед неадаптивних копінг-стратегій - когнітивні неадаптивні стратегії. Серед відносно адаптивних копінг-стратегій переважають когнітивні і поведінкові відносно адаптивні стратегії.
\end{abstract}

Ключові слова: копінг-стратегії, спорт, веслування, кваліфіковані спортсмени.

\section{Вступ}

Стресостійкість $є$ одним з основних критеріїв фізичного і психічного здоров'я спортсмена $[2,7,13]$. Уміння спортсмена подолати стрес і соціальна підтримка знижують вплив стресу на частоту травм $[1,4,9]$. У зв'язку з цим виключно важливою стороною психологічної підготовки спортсмена $\epsilon$ розвиток його здібностей до подолання стресу, формування вміння ефективного використання стратегій подолання стресу (копінг-стратегій) $[3,8,11,15]$. Принцип «адаптивності-неадаптивності» копінг-стратегій міститься в концепції методики Е. Неim [5, 14]. У цілому, адаптивність копінг-стратегій пов'язана 3 цілим рядом позитивних результатів, в тому числі з суб' єктивною оцінкою свого здоров'я, соціальною підтримкою, психосоціальною адаптованістю [8, 12]. Відомо три основних типи копінг-стратегій: 1) стратегії когнітивної адаптації, 2) стратегії поведінкової адаптації і 3) емоційно-орієнтовані стратегії [5, 14].

Психологічне значення копінгу полягає в тому, щоб ефективно адаптувати людину до вимог ситуації [6]. Використання копінг-стратегій можливе не тільки в разі реакції на стрес, подолання стресу, але i для попередження дії стресора, підготовки до можливої стресової ситуації (проактивний копінг) [8]. У цілому, до найбільш продуктивних стратегій подолання труднощів відносять проактивний копінг, стратегії активного подолання проблем, планування діяльності, пошук соціальної підтримки і стратегії гумору. До неефективних у довгостроковій перспективі відносять стратегію уникнення, ухилення від проблем $[1,8,15]$. Слід відзначити, що ефективність копінг-стратегій не є ста- 
більною характеристикою. Так, фокусування уваги на проблемі може бути менш ефективною тактикою подолання стресу, ніж уникнення, якщо супроводжується емоційною інтерпретацією стресової ситуації [11]. 3 практичної точки зору, необхідність дослідження стратегій подолання будь-яких життєвих труднощів, стресу пов'язана 3 важливістю і необхідністю підтримання досягнутої успішності спортивної діяльності та психологічного благополуччя спортсмена $[1,8,13]$.

Безумовно, доцільно досліджувати стрес як комплекс психологічних, психофізіологічних, фізіологічних реакцій спортсменів на стресову ситуацію [1, 13], у тому числі з метою прогнозування ризику травматизму спортсменів. Варто підкреслити, що фізичне виховання розглядається як один з основних педагогічних прийомів формування вміння ефективного використання копінг-стратегій $[1,6]$.

Дослідження проводилося відповідно до держбюджетної науково-дослідної теми «Технологія оцінки ризику травматизму спортсменів за електронейроміографічними і психофізіологічними показниками» (№ держреєстра- ції 0119U000307) Міністерства освіти і науки України.

Мета дослідження полягала у визначенні типів копінг-стратегій, характерних для кваліфікованих спортсменів-веслувальників.

\section{Методи}

У проведеному дослідженні брали участь 43 кваліфікованих спортсмени (МС, МСМК, ЗМС) віком 14-29 років: 27 чоловіків і 16 жінок, представників збірної команди України з веслування на байдарках і каное. Для вивчення стратегій подолання стресу (копінг-стратегій) і визначення пріоритетного стилю подолання стресових ситуацій або проблем у спортсменів був використаний опитувальник «Виявлення індивідуальних копінг-стратегій» Е. Хайма [5, 14], який дозволяв досліджувати 26 ситуаційно-специфічних варіантів копінга, розподілених відповідно до трьох основних сфер психічної діяльності на когнітивний, емоційний і поведінковий копінгмеханізми. Види копінг-поведінки були розподілені Е. Неim на три основні групи за ступенем їх адаптивних можливостей: «адаптивні», «відносно адаптивні» і «неадаптивні» (табл. 1).

Таблиия 1

Копінг-стратегії, класифікація за Е. Неim [5]

\begin{tabular}{|c|c|c|c|}
\hline & У когнітивній сфері & В емоційній сфері & У поведінковій сфері \\
\hline «Адаптивні» стратегії & $\begin{array}{l}\text { «проблемний аналіз», } \\
\text { «установка власної цінності», } \\
\text { «збереження витримки» }\end{array}$ & $\begin{array}{l}\text { «протест», } \\
\text { «оптимізм» }\end{array}$ & $\begin{array}{l}\text { «співпраця», «звернення», } \\
\text { «альтруїзм» }\end{array}$ \\
\hline $\begin{array}{l}\text { «Неадаптивні» } \\
\text { стратегії }\end{array}$ & $\begin{array}{l}\text { «покора», «розгубленість», } \\
\text { «дисимуляція», «ігнорування» }\end{array}$ & $\begin{array}{l}\text { «пригнічення } \\
\text { емоцій», «покірність», } \\
\text { «самозвинувачення», } \\
\text { «агресивність» }\end{array}$ & $\begin{array}{l}\text { «активне уникнення», } \\
\text { «відступ» }\end{array}$ \\
\hline $\begin{array}{l}\text { «Відносно адаптивні» } \\
\text { стратегії }\end{array}$ & $\begin{array}{l}\text { «відносність», «додача сенсу», } \\
\text { «релігійність» }\end{array}$ & $\begin{array}{l}\text { «емоційна розрядка», } \\
\text { «пасивна кооперація» }\end{array}$ & $\begin{array}{l}\text { «компенсація», } \\
\text { «відволікання», } \\
\text { «конструктивна } \\
\text { активність» }\end{array}$ \\
\hline
\end{tabular}

При проведенні комплексних психологічних і біологічних досліджень за участю спортсменів відповідно до принципів біоетики дотримувалися розробленої в лабораторії теорії і методики спортивної підготовки і резервних можливостей спортсменів НДІ НУФВСУ «Програми комплексного біологічного дослідження особливостей функціональних можливостей спортсменів», а також законодавства України про охорону здоров'я та Гельсінської декларації
2000 р., директиви Європейського товариства 86/609 щодо участі людей у медико-біологічних дослідженнях [10].

Статистична обробка результатів проводилася 3 використанням комп’ютерної програми «Microsoft Excel» 3 визначенням основних статистичних показників: середнє арифметичне значення (M), середнє квадратичне відхилення (SD), коефіцієнт варіації (CV,\%), мінімальне і максимальне значення показника у вибірці, медіану та ін. 


\section{Результати та обговорення}

Одним із завдань нашого дослідження було виявлення типів копінг-поведінки кваліфікованих спортсменів-веслувальників. Було проведено дослідження стратегій подолання життєвих труднощів у спортсменів для подальшого порівняння отриманих результатів з наявності або відсутності травм у групах 3 «адаптивними», «відносно адаптивними» і «неадаптивними» стратегіями подолання стресу. Як видно з даних, представлених у таблиці 2, найменша різниця при розподілі спортсменів на групи в залежності від вибору ними копінг-стратегій («адаптивних», «не адаптивних» чи «відносно адаптивних») виявлена для когнітивної сфери, що характеризує певні уміння і навики, якими володіє спортсмен. Це уміння спортсмена ставити конкретні цілі та планувати етапи ії досягнення, здатність до концентрації на досягнення мети, а також гнучкість реагування на зміну ситуації. Обробка даних, отриманих у ході дослідження за методикою Е. Хайма, показала такі результати: для $37,21 \%$ спортсменів було характерним використання когнітивних адаптивних стратегій, до яких належать «проблемний аналіз», «установка власної цінності» та «збереження витримки».

Таблиия 2

Копінг-стратегії спортсменів-веслувальників за тестом Е. Неіт (n=43)

\begin{tabular}{|c|c|c|}
\hline Копінг-стратегії & $\begin{array}{c}\text { Кількість } \\
\text { спортсменів, n, }\end{array}$ & $\begin{array}{c}\text { Кількість } \\
\text { спортсменів, \% }\end{array}$ \\
\hline \multicolumn{3}{|c|}{ Когнітивні копінг-стратегії } \\
\hline «Адаптивні» стратегії & 16 & $37,21 \%$ \\
\hline «Неадаптивні» стратегії & 12 & $27,91 \%$ \\
\hline «Відносно адаптивні» стратегії & 15 & $34,88 \%$ \\
\hline \multicolumn{3}{|c|}{ Емоційні копінг-стратегії } \\
\hline «Адаптивні» стратегії & 34 & $79,07 \%$ \\
\hline «Неадаптивні» стратегії & 8 & $18,60 \%$ \\
\hline «Відносно адаптивні» стратегії & 1 & $2,33 \%$ \\
\hline \multicolumn{3}{|c|}{ Поведінкові копінг-стратегії } \\
\hline «Адаптивні» стратегії & 22 & $51,16 \%$ \\
\hline «Неадаптивні» стратегії & 5 & $11,63 \%$ \\
\hline «Відносно адаптивні» стратегії & 16 & $37,21 \%$ \\
\hline
\end{tabular}

У 34,88 \% спортсменів використовувалися когнітивні «відносно адаптивні» стратегії (див. табл. 2), до яких належать: «відносність», «додача сенсу», «релігійність». Слід відмітити, що конструктивність «відносно адаптивних» варіантів копінг-поведінки залежить від значущості й вираженості ситуації, яку необхідно подолати. Когнітивні «неадаптивні» стратегії були виявлені у 27,91 \% спортсменів. До «неадаптивних» варіантів копінг-поведінки серед когнітивних копінг-стратегій належать: «покора», «розгубленість», «дисимуляція», «ігнорування».

Найбільш виражені відмінності під час вибору копінг-стратегій виявлені для емоційних «адаптивних» копінг-стратегій. Так, для 79,07 \% спортсменів був характерним вибір емоційних «адаптивних» варіантів копінг-стратегій, до яких належать «протест» і «оптимізм». Використання емоційних «відносно адаптивних» стратегій було властиво для 2,33 \% спортсменів: «емоційна розрядка», «пасивна кооперація».
Серед емоційних копінг-стратегій до «неадаптивних» варіантів копінг-поведінки належать: «пригнічення емоцій», «покірність», «самозвинувачення» та «агресивність» і використання їх виявилося властивим для 18,6 \% спортсменів (див. табл. 2).

Використання поведінкових «адаптивних» копінг-стратегій виявлено в 51,16 \% спортсменів. Серед поведінкових копінг-стратегій до «адаптивних» варіантів копінг-поведінки відносимо: «співпраця», «звернення», «альтруїзм», під якими розуміється така поведінка особистості, при якій вона вступає в співпрацю зі значимими (більш досвідченими) людьми, шукає підтримки в найближчому соціальному оточенні або сама пропонує ії близьким під час подолання труднощів. Використання «відносно адаптивних» поведінкових стратегій («компенсація», «відволікання», «конструктивна активність») було характерним для 37,21\% спортсменів (див. табл. 2), поведінка яких характеризу- 
валася прагненням до тимчасового відходу від вирішення проблем.

Поведінкові «неадаптивні» стратегії діагностовано у 11,63 \% спортсменів. Серед поведінкових копінг-стратегій до «неадаптивних» варіантів копінг-поведінки відносимо «активне уникнення», «відступ», що характеризують поведінку, яка передбачає уникнення думок про неприємності, пасивність, усамітнення, спокій, ізоляцію, прагнення усунутися від активних інтерперсональних контактів, відмова від вирішення проблем.

Таким чином, найбільш поширеними копінг-стратегіями серед обстежених спортсменів були: в когнітивної сфері - «проблемний аналіз»; в емоційній сфері - «оптимізм»; в поведінкової сфері - «відволікання».

У цілому, серед спортсменів кількісно переважало використання «адаптивних» стратегій у порівнянні з «неадаптивними» i «відносно адаптивними». Серед «адаптивних» копінг-стратегій найбільш поширеними в спортсменів були емоційні «адаптивні» стратегії. Серед «неадаптивних» копінг-стратегій найбільш поширеними в спортсменів були когнітивні «неадаптивні» стратегії. Серед «відносно адаптивних» копінгстратегій переважали когнітивні і поведінкові «відносно адаптивні» стратегії (див. табл. 1).

\section{Перспективи подальших досліджень}

Цікавим $є$ подальше дослідження з проведенням порівняльного аналізу психологічних і психофізіологічних показників у спортсменів, які спеціалізуються в різних видах спорту, а також для подальшого аналізу результатів відносно наявності або відсутності травм у групах з «адаптивними», «відносно адаптивними» i «неадаптивними» стратегіями подолання стресу з урахуванням результативності змагальної діяльності.

\section{Висновки}

1. Найбільш поширеними стратегіями подолання стресу серед кваліфікованих спортсменів-веслувальників були: в когнітивній сфері «проблемний аналіз», в емоційній сфері - «оптимізм»; в поведінковій сфері - «відволікання».

2. Серед кваліфікованих спортсменів-веслувальників кількісно переважало використання адаптивних стратегій у порівнянні $з$ неадаптивними і відносно адаптивними.

3. Серед адаптивних копінг-стратегій найбільш поширеними у спортсменів були емоційні адаптивні стратегії, а серед неадаптивних копінг-стратегій - когнітивні неадаптивні стратегії. Серед відносно адаптивних копінг-стратегій переважали когнітивні і поведінкові відносно адаптивні стратегії.

\section{References}

1. Bochaver KA, Dovzhik LM. Coping behavior in professional sports: phenomenology and diagnosis. The electronic journal «Klinicheskaya i spetsial'naya psikhologiya». 2016; 5, 1: 1-18. DOI: 10.17759/psyclin.2016050101

Бочавер КА, Довжик ЛМ. Совладающее поведение в профессиональном спорте: феноменология и діагностика. Электронный журнал «Клиническая и специальная психология». 2016; 5, 1 : 1-18. DOI: $10.17759 /$ psyclin.2016050101

2. Fedorchuk S, Lysenko E, Shynkaruk O. Constructive and non-constructive coping strategies and psychophysiological properties of elite athletes. European Psychiatry. Elsevier, 2019; 56: 306.

3. Fedorchuk S, Tukaiev S, Lysenko O, Shynkaruk O. The psychophysiological state of highly qualified athletes performing in diving with different levels of anxiety. European Psychiatry. Elsevier, 2018; 48: 681 .

4. Hardy CJ, Richman JM, Rosenfeld LB. The role of social support in the life stress/injury relationship. Sport Psychol. 1991; 5, 128: 39.
5. Heim E. Coping based intervention strategies. Patient education and counseling. 1995; 26(1-3): 145-151.

6. Pichurin VV. Coping strategies and psychological readiness of students for professional work. Pedahohika, psykholohiya ta medyko-biolohichni problemy fizychnoho vykhovannya i sportu. 2015; 2: 53-59.

Пічурін ВВ. Копінг-стратегії студентів і психологічна готовність до професійної праці. Педагогіка, психологія та медико-біологічні проблеми фізичного виховання і спорту. 2015; 2: 53-59.

7. Platonov VN. The system of training athletes in the Olympic sport. General theory and its practical applications. Kyiv: Olympic literature; 2015. 680 p. Платонов ВН. Система подготовки спортсменов в олимпийском спорте. Общая теория и ее практические приложения: учебник. К.: Олимп. лит.; 2015. Кн. 1.680 с.

8. Rasskazova EI, Gordeev TO, Osin EN. Coping strategies in the structure of activity and selfregulation: psychometric characteristics and 
possibilities of applying the COPE methodology. Psikhologiya. Zhurnal VSE. 2013; 1: 82-118. Рассказова ЕИ, Гордеева ТО, Осин ЕН. Копингстратегии в структуре деятельности и саморегуляции: психометрические характеристики и возможности применения методики СОРЕ. Психология. Журнал ВШЭ. 2013; 1: 82-118.

9. Sarason I.G., Sarason J.H., Pierce G.R. Social support, personality, and performance. J. Appl. Sport Psychol. 1990; 2, 117: 27.

10. Shinkaruk OA, Lysenko OM, Gunin LM, Karlenko VP, Zemtsova II, Olishevsky SV. etc. Medicobiological support of training of athletes of national teams of Ukraine on Olympic sports. Kyiv: Olympic literature; 2009. $144 \mathrm{p}$

Шинкарук ОА, Лисенко ОМ, Гуніна ЛМ, Карленко ВП, Земцова II, Олішевський СВ. та ін. Медико-біологічне забезпечення підготовки спортсменів збірних команд України з олімпійських видів спорту. К.: Олімпійська література; 2009. $144 \mathrm{c}$.

\section{Інформація про авторів:}

\section{Федорчук Світлана}

Національний університет фізичного виховання і спорту України, Київ, Україна
11. Suls J, Fletcher B. The relative efficacy of avoidant and nonavoidant coping strategies: A meta-analysis. Health Psychology. 1985; 4(3): 249-288.

12. Vaillant GE. Adaptive mental mechanisms. Their role in a positive psychology. American Psychologist. 2000; 55, 1: 89-98.

13. Voronova VI. Sport Psychology: textbook for students of higher educational institutions. Kyiv: Olympic literature; 2007. 298 p.

Воронова ВІ. Психологія спорту: [навч. посіб. для студ. вищ. навч. закл. К.: Олімп. л-ра.; 2007. 298 с.

14. Wasserman LI, Ababkov VA, Trifonova EA. Coping with stress. Theory and psychological testing. SPb: Rech; 2010. 192 p.

Вассерман ЛИ, Абабков ВА, Трифонова ЕА. Совладание со стрессом. Теория и психодиагностика. СПб.: Речь; 2010. 192 с.

15. Weinberg RS, Gould D. Sport Psychology. Kyiv: Olympic literature; 2014. 335 p.

Вейнберг РС, Гоулд Д. Психологія спорту. К.: Олімп. л-ра.; 2014. 335c.

\author{
Лисенко Олена \\ https://orcid.org/0000-0002-1239-2596 \\ Київський Університет імені Бориса Грінченка, Київ, Україна \\ o.lysenko@kubg.edu.ua \\ Отримано: 04.06.2019; \\ Прийнято 17.06.2019; Опубліковано: 28.06.2019.
}

